\title{
THE GREAT GRAY OWL IN MANITOBA, 1968-83
}

ROBERT W. NERO, Wildlife Branch, Box 14, 1495 St. James Street, Winnipeg, Manitoba, R3H OW9, HERBERT W.R. COPLAND, Manitoba Museum of Man and Nature, 190 Rupert Avenue, Winnipeg, Manitoba, R3B ON2 and JOSEPH MEZIBROSKI, 26 Pearce Avenue, Winnipeg, Manitoba, R2V 2K4.

Most owls hunt mainly at night, but the Great Gray Owl is an exception. In winter, especially, this species may hunt all day long. Bold and large, and frequently perched in leafless deciduous trees, they are notably conspicuous. These owls attract much attention when they wander far outside of their usual breeding range and into settled areas, but they also may be seen in winter within their breeding range. In recent years, looking for Great Gray Owls has become an annual winter pastime in suitable areas of southern Manitoba. This report reviews the seasonal sightings of this species in this region for the 15 years from 1968 through 1983, but breeding information for this period is also briefly presented.

Special attention was drawn to the Great Gray Owl in Manitoba late in 1964 when visiting ornithologist David F. Parmelee submitted a nest record card to the Prairie Nest Records Scheme. This nest was discovered near Phil Reader's home 16 km (10 mi.) north of The Pas, and was only the second one known for the province. ${ }^{15}$ In 1968, Reader found Great Gray Owls using the same nest. Nero and Robert R. Taylor drove about 800 $\mathrm{km}$ (500 mi.) from Winnipeg to observe and photograph these owls. ${ }^{8}$ This provided Taylor's first photographs of Great Gray Owls, a quest which he has pursued ever since. The following winter (1968-69), as if by magic, larger numbers of Great Gray Owls were observed in southern Manitoba than had previously been re-

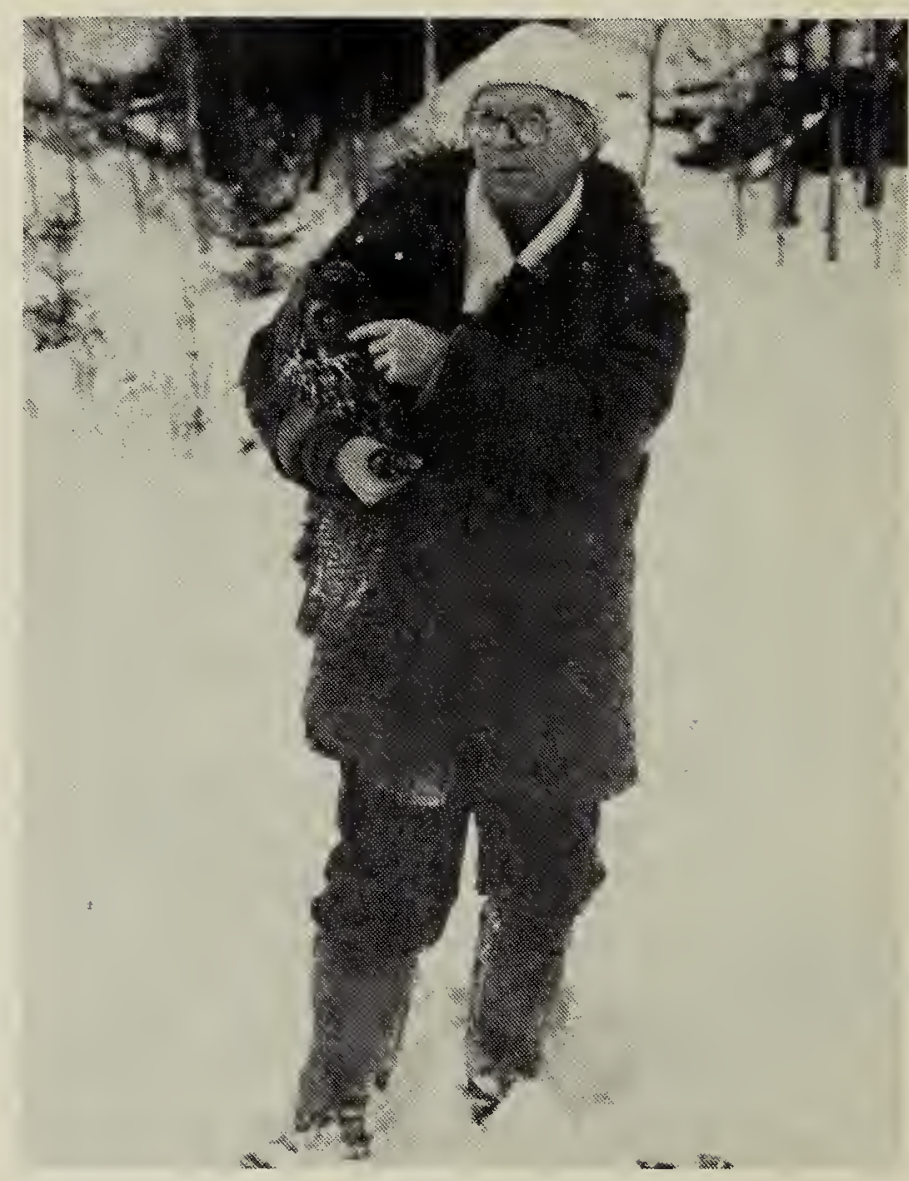

Nero with adult male Great Gray OwI Robert R. Taylor

corded. That winter, Copland, Nero and Taylor trapped and banded Great Gray Owls for the first time. During the same period, hundreds of Manitobans had their first look at this magnificent bird. Subsequently, the provincial status of this species was reviewed in some detail; all known records (including nests) were reported. 7 A few records which had been overlooked and records for winter 1969-70 were published the following year. ${ }^{9}$ In spring 1970 , considerable interest was stimulated by the discovery of an active nest about $5 \mathrm{~km}$ ( 3 mi.) south of South Junction, Manitoba, just across the border in Minnesota and less than $160 \mathrm{~km}$ (100 mi.) southeast of Winnipeg. ${ }^{6} 10$ 
Thereafter, a concerted effort was made to learn more about the occurrence of this species in the region. For a few years in spring and summer, aided by Bob Taylor and Spencer $G$. Sealy, efforts were made to find active nests. A man-made nest, built in July 1970 to attract Great Gray Owls, was used by a pair in 1974. ${ }^{14}$ Now more than 100 nest structures have been installed. This endeavour was carried out mainly by Copland and.Nero (and members of the Nero family), and notably by Raymond Tuokko. ${ }^{11}$ Accounts of more than 50 active natural and man-made nests recorded since 1970 (Map 3) will hopefully be given at a later time. From 1975-77, K. Michael Collins, working under Spencer Sealy, studied owls at two successful nests about $83 \mathrm{~km}$ ( $50 \mathrm{mi}$.) east of Winnipeg, and one aborted nesting south of South Junction, producing a thesis for a master's degree at the University of Manitoba.

By about 1975, it had become clear that the Great Gray Owl, in addition to being resident over much of the mixed woods and coniferous forest regions of the province, was a not uncommon breeding species in extreme southeastern Manitoba and adjacent Minnesota. Much information on the habits and occurrence of the Great Gray Owl in this region was brought together in a comprehensive book, authored by Nero and copiously illustrated by Bob Taylor, published in 1980. ${ }^{12}$ Copland and Nero have continued to work as a team, driving more than $10,000 \mathrm{~km}$ some winters to capture and band owls, and banding owls at nests. No one could have guessed, in 1968, that by spring 1984 more than 450 Great Gray Owls (about 100 young and 350 grown birds) would have been banded in this region (Table 1 ).

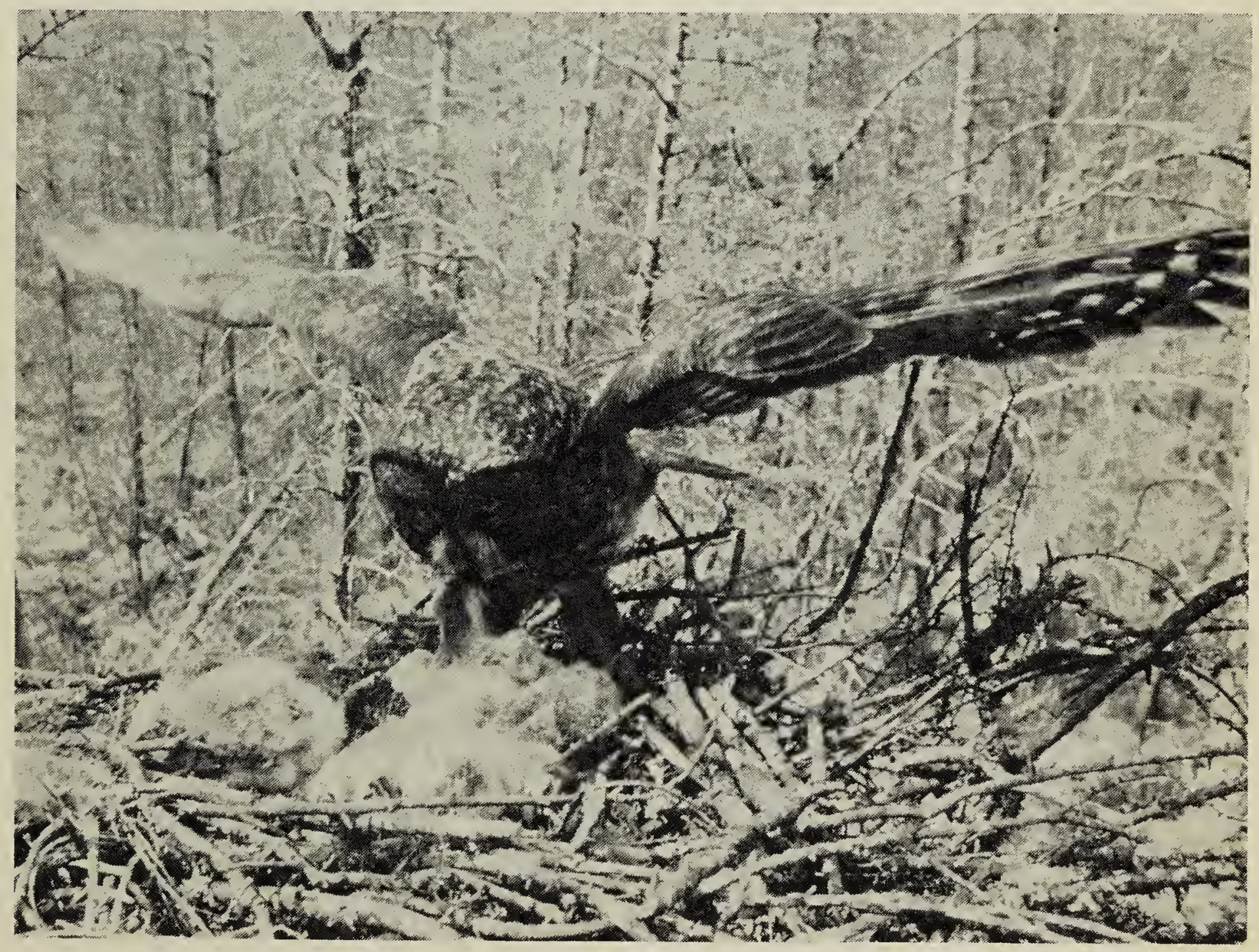




\section{Methods}

Since 1968, Nero has been compiling observations of Great Grays for Manitoba (records from No. 310 high-

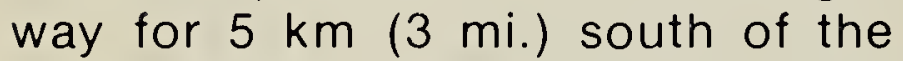
border south of South Junction, Manitoba, are included in this report). To obtain records, extensive publicity was undertaken, including lectures, radio and TV broadcasts, newspaper articles, distribution of illustrated posters, publication of articles and hundreds of phone calls. Many records were obtained from the public, from staff of the Department of Natural Resources, and other government employees. Canadian and U.S. customs and immigration officials at the ports of Middlebro and especially South Junction also provided information.

Observations were requested throughout the province, but Copland and Nero mostly worked in areas where birds were being observed and reported. In late winter 1979, for example, they banded 21 owls in the northern Interlake region. One winter they drove to The Pas, and in two summers they drove to Bissett and Wabowden to band birds at nests. In order to band as many owls as possible, it was to known sites that efforts were directed. Even in the absence of reports, certain key areas were covered once or twice in suitable weather.

We have collated records for more than a 15-year period - 1968 to October 1983. Mezibroski, as a STEP student in the Wildlife Branch in summer 1982 and 1983, undertook to tabulate these records in his spare time, counting and recording the number of sightings on a monthly basis, on an annual winter basis and on an annual basis. The winter period was arbitrarily defined as the time from October through April when owls were most visible. Many co-operators, out looking for birds in general in summer, would have observed owls had they been visible, and we always kept an eye out for them when we were travelling during the nest-checking period of our activities. At first an attempt was made to eliminate bias introduced by observers reporting sightings of what could be the same birds by lumping records for the same place or date, but this was dropped in favour of a total count, so that the figures reveal not so much the number of owls present as their visibility, that is, the total number of sightings.

By banding birds in winter, some absolute counts were obtained. In addition, colour marking (carried out in some years) provided an opportunity to estimate numbers of owls by comparing the number of marked to unmarked birds. Numbers of individuals seen in one day, or in two consecutive days, permitted a direct count, sometimes of substantial numbers. Numbers of dead owls, even, sometimes offered astonishingly high counts (see below). Colour marking also provided a means of determining movements of birds; more precise information on movement was gained in the winter of 1982-83 when individuals were identified by numbered tags.

\section{Results}

OWL SIGHTINGS: For the 15-year period 3,360 sightings of Great Gray Owls were recorded by 641 different observers. These records would have greater meaning if there was some means of calculating an index relating number of sightings to "observer hours" or "kilometres driven". This could be done for observations by Copland and Nero who regularly searched for owls, and who kept such records, but their observations are a small part of the total (e.g. for the winter of 1978-79, when 629 observations were recorded, only 49 or $7 \%$ were made by Copland and/or Nero). 


$\begin{array}{lccc}\text { Year } & \text { Winter } & \text { Year } & \text { Summer } \\ 1968-69 & 6 & 1969 & 0 \\ 1969-70 & 0 & 1970 & 4 \\ 1970-71 & 0 & 1971 & 0 \\ 1971-72 & 0 & 1972 & 0 \\ 1972-73 & 0 & 1973 & 1 \\ 1973-74 & 23 & 1974 & 3 \\ 1974-75 & 2 & 1975 & 0 \\ 1975-76 & 2 & 1976 & 13 \\ 1976-77 & 0 & 1977 & 15 \\ 1977-78 & 34 & 1978 & 7 \\ 1978-79 & 88 & 1979 & 22 \\ 1979-80 & 50 & 1980 & 41 \\ 1980-81 & 29 & 1981 & 13 \\ 1981-82 & 2 & 1982 & 1 \\ 1982-83 & 26 & 1983 & 6\end{array}$

Summer banding mainly females and young. (Number banded winter 1983-84: 71)

For most observers, owls were encountered by chance, and hours involved or distances travelled were not recorded. Nevertheless, the sightings provide substantial evidence of the occurrence and distribution of owls and there is good reason to believe that the annual numerical differences (Figure 2 and Table 1) represent real variations. To some extent the number of sightings reflects the relative number of owls present, particularly reports received in a short period of time and over a large area. There is a good correlation between the number of sightings in any one winter and the number of birds that were banded (compare Figure 2 and Table 1). Incidentally, our ability to capture owls had increased greatly by late winter 1973-74.

The distribution of sightings by month is shown in Figure 1. Note that most observations are for the winter period (October through April). It will be noted that there are more observations for May than for October; it may be concluded that we should have included October in the "summer" period. April, admittedly, is a variable month for sightings; in some early springs, following the disappearance of snow, owls may not be observable. Sightings in summer (defined here as the period from May through September) were relatively scarce, probably owing to a change in owl activities. For most of the year Great Gray Owls are inconspicuous, but in certain winters many individuals may be found perched near highway rights-of-way and roads, hunting in adjacent grassy and weedy open areas. They also hunt on the edges of openings in the forest; some of our records were obtained from hunters, loggers, skiers and others travelling or working within forested areas. Narrow roads where there is little or no ditch seldom attract owls; birds encountered in such situations are usually wary and soon leave. In our experience, dull, overcast and calm days bring out more birds, but sometimes when it is calm they may 


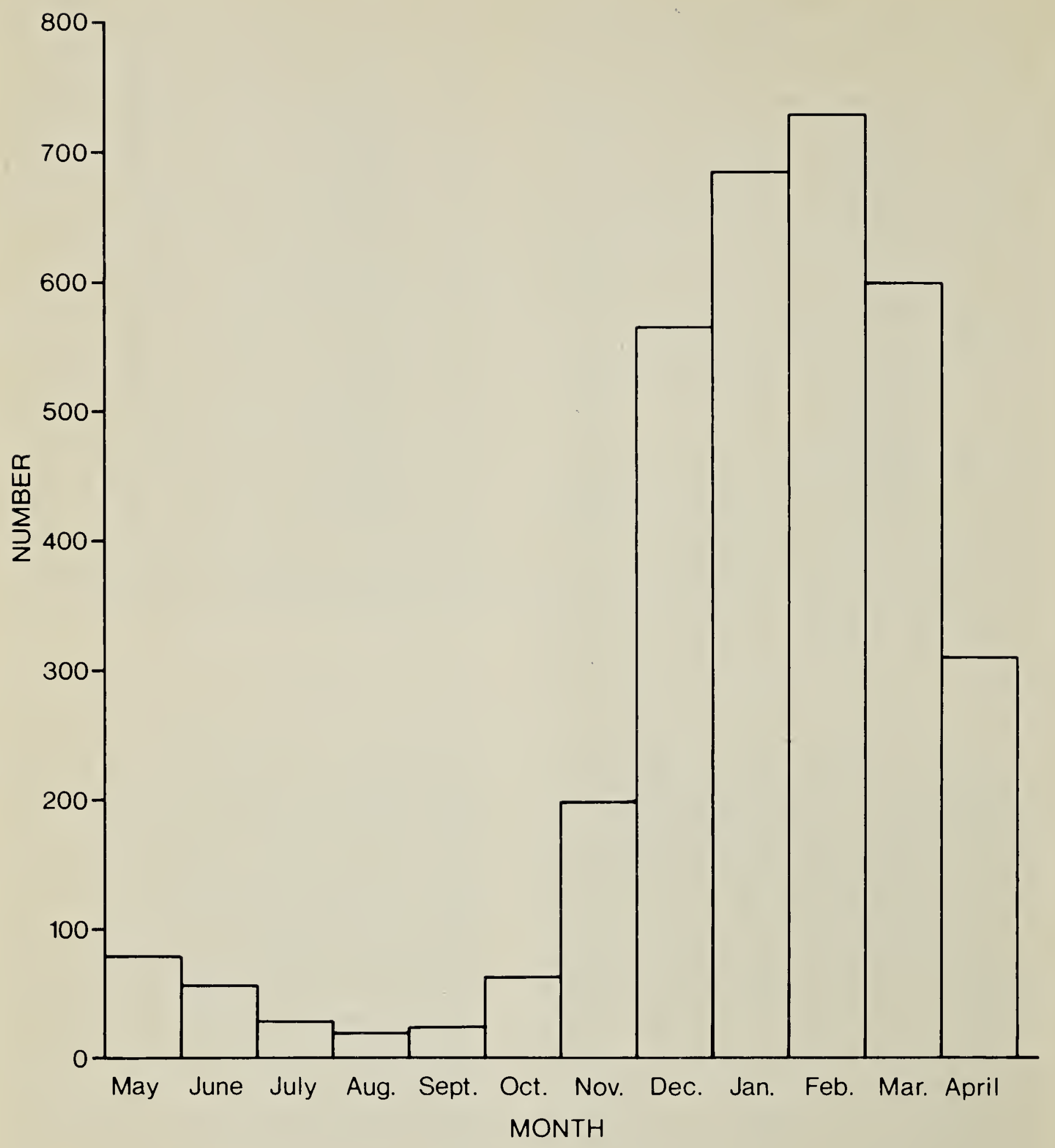

Figure 1. Sightings of Great Gray Ow/s, monthly totals, 1968-83.

be out even on bright, sunny days. Generally, more owls may be seen during the early morning and late evening hours. Days when it is calm and heavily overcast (or foggy or snowing) seem to provide optimum conditions. In some instances, especially close to the breeding season in mid-February and March, it seemed that owls were out for social reasons as much as for food. Thus, the broad outlook provided by a highway or other open expanse may have some social function.

One unusual aspect of owls in winter is a tendency for them to appear in favoured areas in successive years. Different birds (as determined by banding) use the habitat in the same way as previous occupants, suggesting that they are attracted not 
only by small mammals, but also by landscape features, particular configurations of woods and fields. From year to year we have learned that we are successful if we search for owls in certain places. One year on three successive weekends we banded three different owls in almost the same group of trees. If we had not been colour-marking them, we would have assumed that we were looking at the same bird. This merits further study.

The graph of annual total numbers of winter sightings (Figure 2) shows considerable variation from year to year. Sightings range from 23 in winter 1975-76, when the study was well under way and a large number of people were looking for owls, to 629 in winter 1978-79. The distribution of sightings is of special interest. Of 3,149 winter sightings for the region, 2,354 or $75 \%$ of the total number were

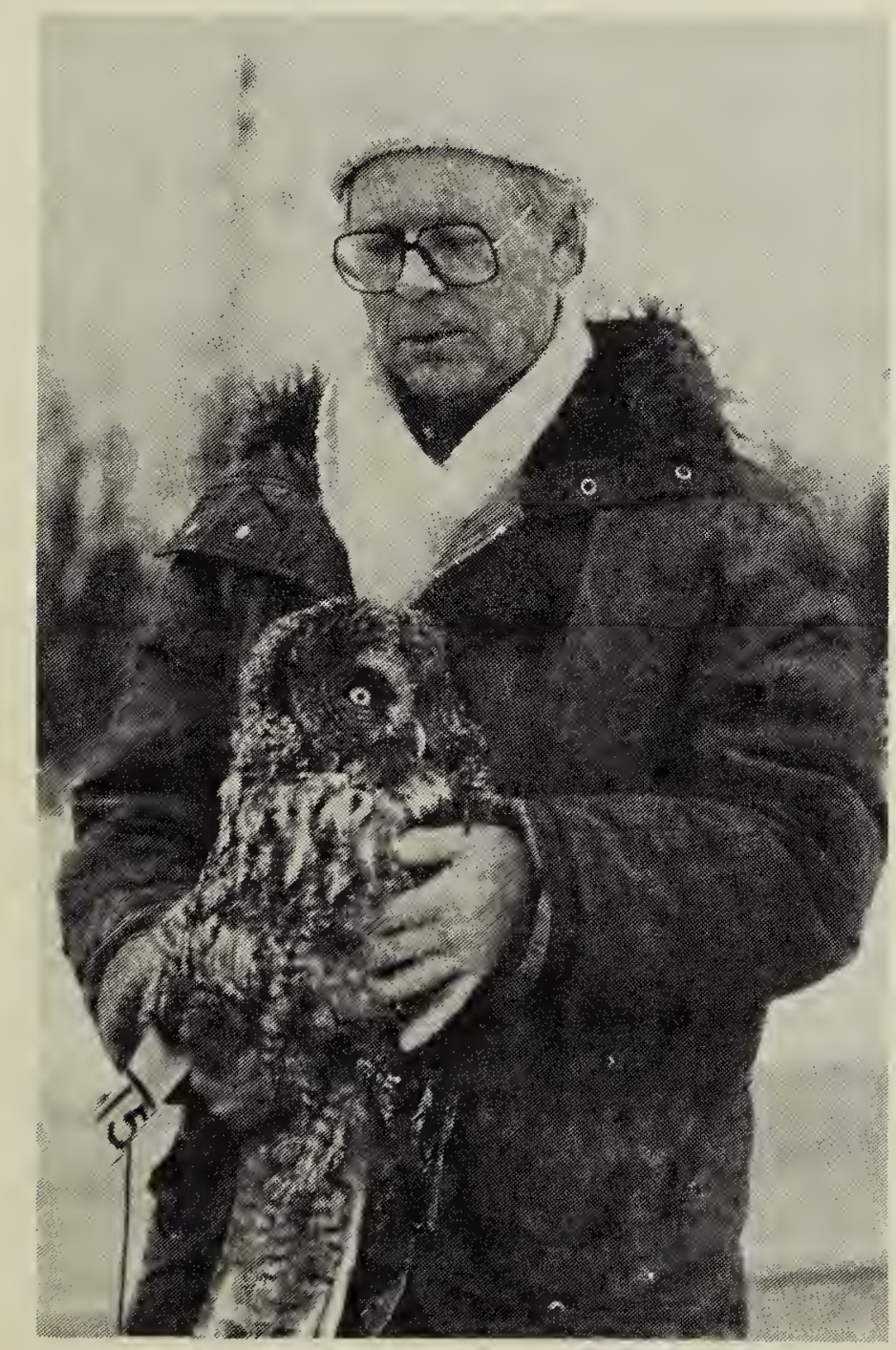

Nero with banded and tagged adult female. made within a rectangular area 106 $\mathrm{km} \times 184 \mathrm{~km}$ (66 mi. $\times 115 \mathrm{mi}$.) in extreme southeastern Manitoba (see Map 1). This may be due to a combination of factors - a wide network of roads, numerous observers, and because it is particularly attractive to owls, both residents and visitants. Ecologically, the area is mainly mixedwood forest with a fairly large amount of black spruce-tamarack bog. Nero noted: "Here, a band of black spruce and tamarack-muskeg country a few dozen miles wide and a hundred miles from north to south lies adjacent to the rocky Precambrian Shield region.... A mixture of old burns, cleared forest, marginal cropland, abandoned fields, grassy meadows, pine and spruce woods, bogs and streams...."12 The area appears to be unique in Manitoba.

The remaining $25 \%$ or 795 sightings were made throughout a large portion of the province, from Riding Mountain National Park in the west, north to far northern areas such as Cranberry Portage, Snow Lake, Thompson, Gillam and even Churchill (Map 1).

Some winters, few owls are seen despite extensive efforts to find them. Note, for example, the scarcity of observations for the winters of 1970-71, 1972-73and 1975-76 (Figure2), years when a special effort was made to obtain observations and at a time when there had already been considerable publicity. There is evidence that in these winters owls still are present but, presumably because they are able to find sufficient food within the forest they are seldom out on roadsides, at least in the daytime. There is information showing that in some winters owls simply were not visible along roads even in known breeding grounds and sites where owls were known to be present within the forest. It is not possible to estimate the numbers of such birds in these years, although active nests in the following season provide some indication. 


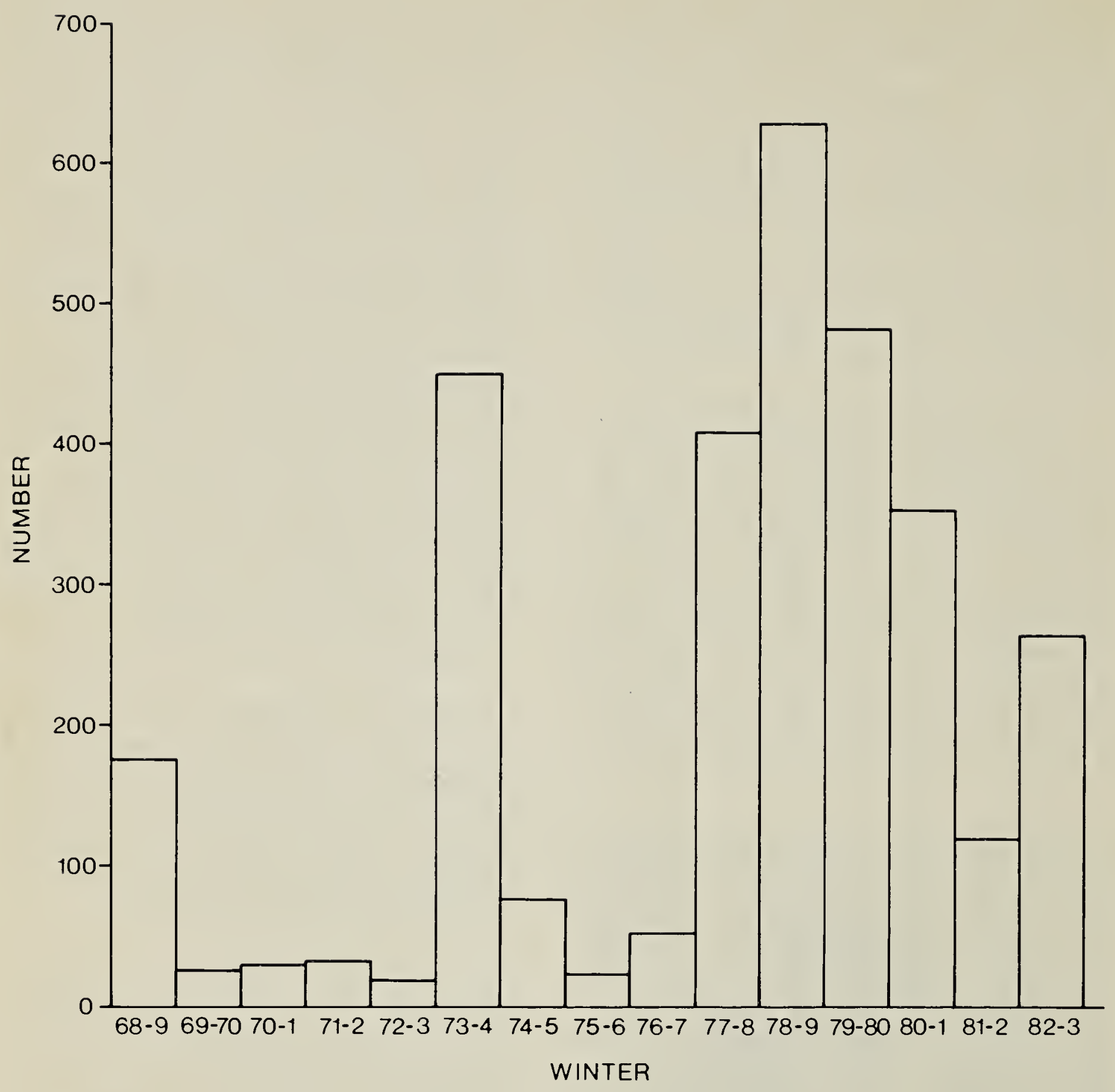

Figure 2. Winter sightings (3149) of Great Gray Ow/s, annual totals 1968-69 through 1982-83.

On the other hand, if there is a scarcity of food within a particular area, local populations may move elsewhere. Stephen L. Loch has shown that a radio-marked Great Gray Owl emigrated from a breeding area in Minnesota to haunts in Ontario approximately $275 \mathrm{~km}$ (165 mi.) away in less than a month's time (pers. comm., 1981). At this rate of travel, it is easy to understand that owls could, in a rela- tively short period of time, move completely across southeastern Manitoba to find a suitable supply of prey. This may be the way in which winter concentrations of 5 to 50 owls develop in a few days or weeks.

Some winters, owls apparently move from northern areas into more southerly parts, such movements occasionally being accompanied by numbers 


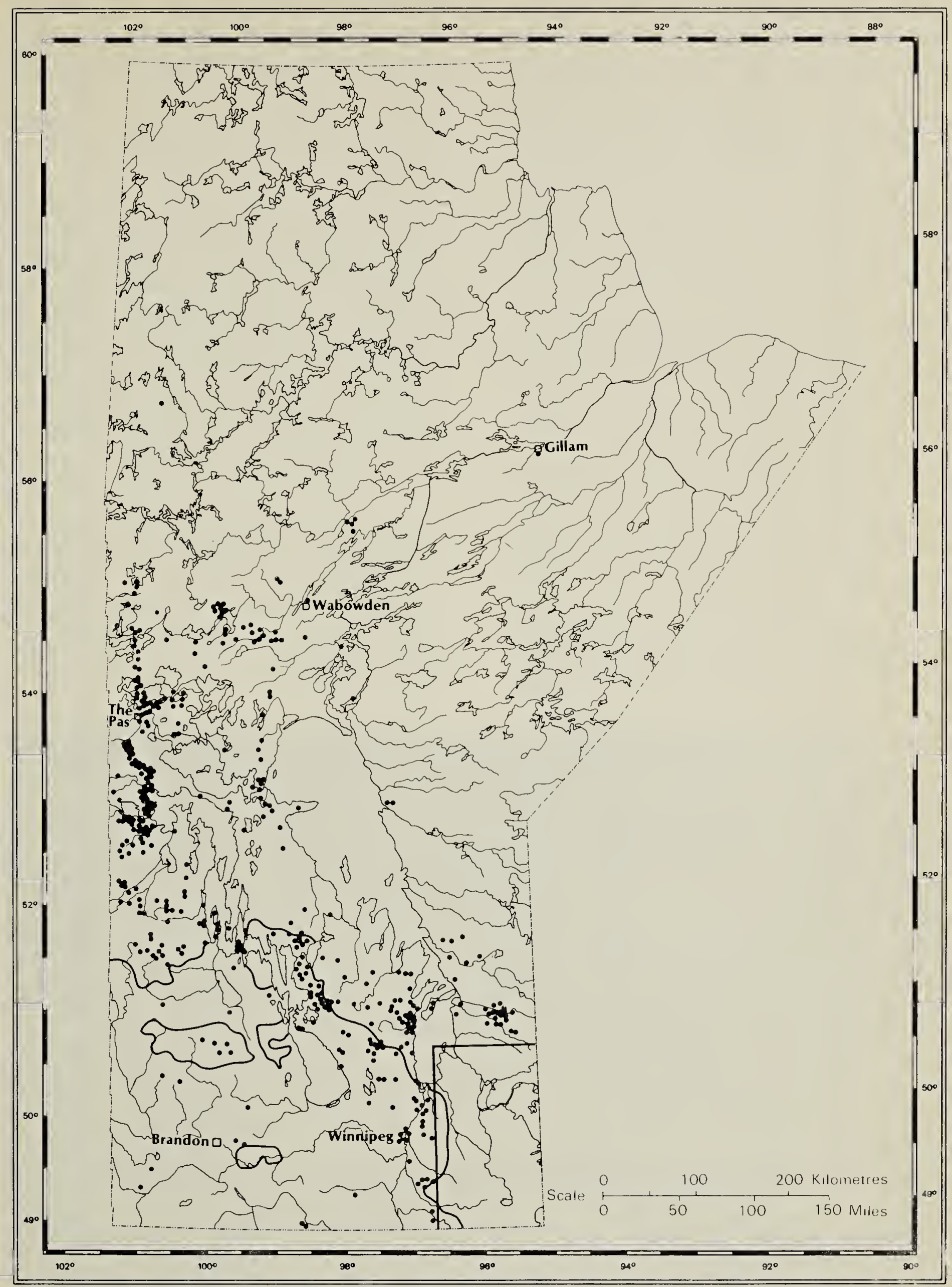

Map 1. Winter sightings of Great Gray Ow/s 1968-69 through 1982-83, excluding the southeastern corner where 75\%(2354) of winter sightings occurred. Dots represent sightings; heavy lines show the southern boundary of the mixedwood region and outlying areas. 
of Northern Hawk-Owls, a species that obviously comes from farther north. According to Heimo Mikkola, a noted Finnish owl specialist, the invasions of the Great Gray Owl (in Eurasia) manifest the same dynamics as the Northern Hawk-Owl. In years with a normal vole population most Great Gray Owls spend the winter in the breeding region; during mass dieoffs of voles, however, conspicuous invasions occur and these owls wander in all directions within the coniferous zone (from a translation). ${ }^{4}$ Great Gray Owls also move northwards from southern breeding grounds. Band recoveries of owls in winter in extreme southeastern Manitoba consist of local residents as well as some birds from northern Minnesota (e.g. a bird captured east of Winnipeg on 5 April 1981 had been banded by Loch on 10 April 1978, about $357 \mathrm{~km}$ (223 mi.) to the southeast). ${ }^{13}$ This has also been demonstrated by Loch's work with radio- marked Great Gray Owls in centraleastern Minnesota where most members of a local breeding population moved northwards over winter into northern Minnesota and adjacent Ontario (pers. comm., 1984).

Despite the presence of a fairly abundant resident population of owls in southern Manitoba, surprisingly few birds have been sighted outside the mixedwood region (Map 1). There have been no occurrences here of the kind of influx of owls far outside the breeding range, as observed at intervals in southern Ontario, Quebec and the New England States. ${ }^{20}$

From May through September owls were sighted over the 15-year period in relatively low numbers compared to winter (Figure 1, Maps 1 and 2). Records for 14 summers (1970-83) for which there are observations (apart from owls seen at nests, or family

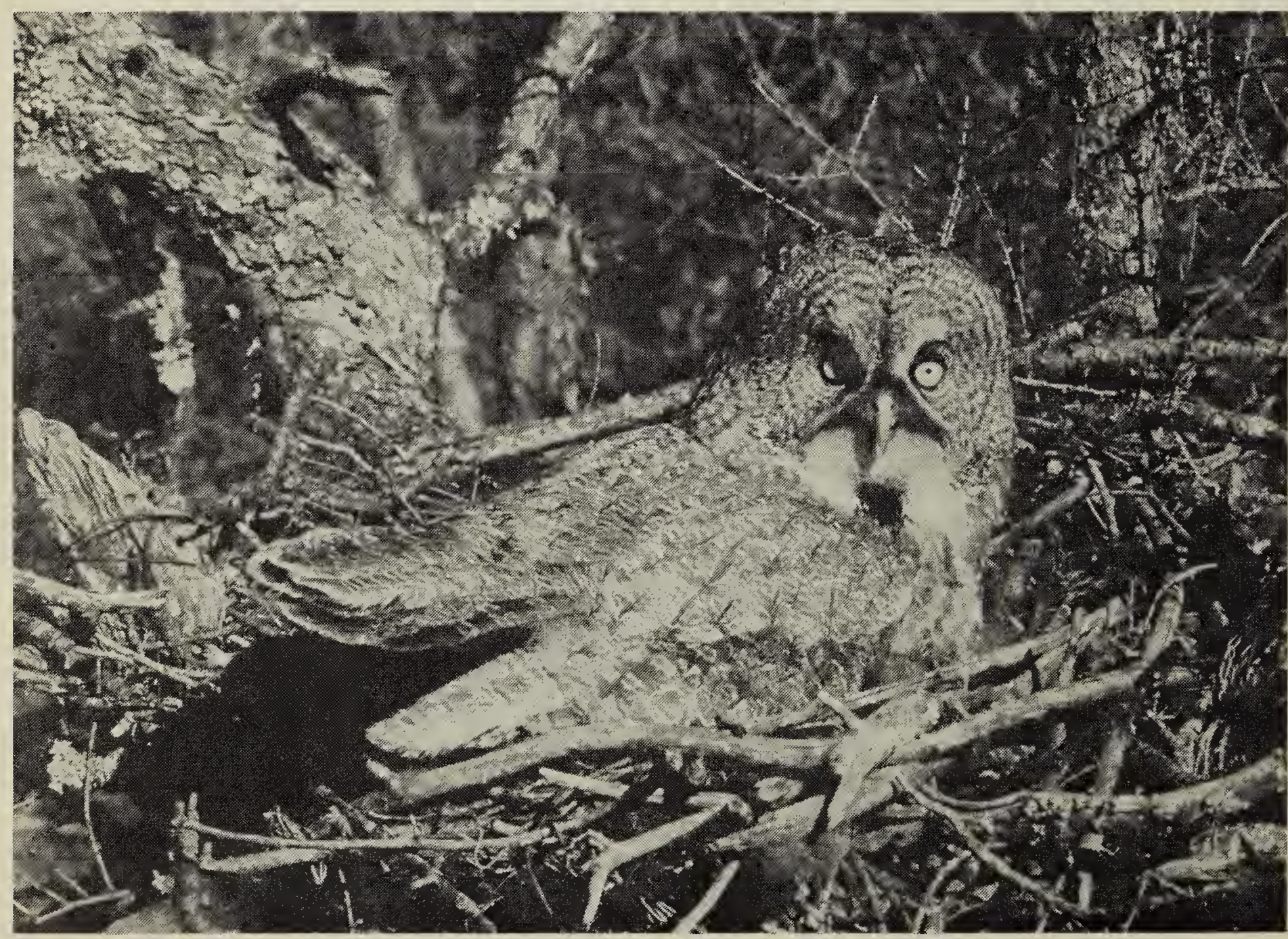

Incubating female. Spreading of the bristle feathers that normally cover the bill denotes anxiety Robert R. Taylor. 
groups) are as follows: May -1 to 16 sightings (average 5.1), June -0 to 9 (av. 3.6), July -0 to 5 (av. 2.1), August -0 to 5 (av. 1.3) and September -0 to 7 (av. 1.8). For the entire period there were only 4 months with 10 or more records. Note that the highest summer count of 16 is for May 1978; winter sightings prior to that summer were high and peaked the following winter. In summer the Great Gray Owl is an elusive bird except at its nest. Even where active nests were less than 100 yards off roads, birds were seldom observed. Thus, except in certain winters, this species behaves like most owls, keeping well within its woodland habitat.

A feature which may affect the number and winter appearances of owls is the annual variation in the production of young. The Great Gray Owl's reproductive potential is fairly high; three to four eggs per nest is average, but as many as six have been found here. Mikkola points out that in Scandinavia the clutch size and the fluctuations in egg number are largest with the Great Gray Owl (among the Strix owls), which is the most specialized for restricted prey, namely small rodents and shrews. He notes further that in this respect the Great Gray Owl more resembles the Snowy Owl and the Northern Hawk-Owl and the Asio species than it does two of its nearest relatives, the Tawny and Ural owls. Mikkola states that the size of the clutch of the Great Gray Owl changes in accordance with the size of the vole population, so that there are significant differences between years of a high and a low vole population. In Finland and Sweden the number of fledged juveniles is highest when vole populations are high. "The fact that the young triple their weight within five days and weigh about 500 grams at 14 days (with a hatching weight of 40 grams) illustrates indirectly that a rich food supply is essential for their survival. It is easy to understand how this owl, as a decided specialist, reacts so sensitively to changes in the density of the supply of small mammals" (translated). ${ }^{4}$

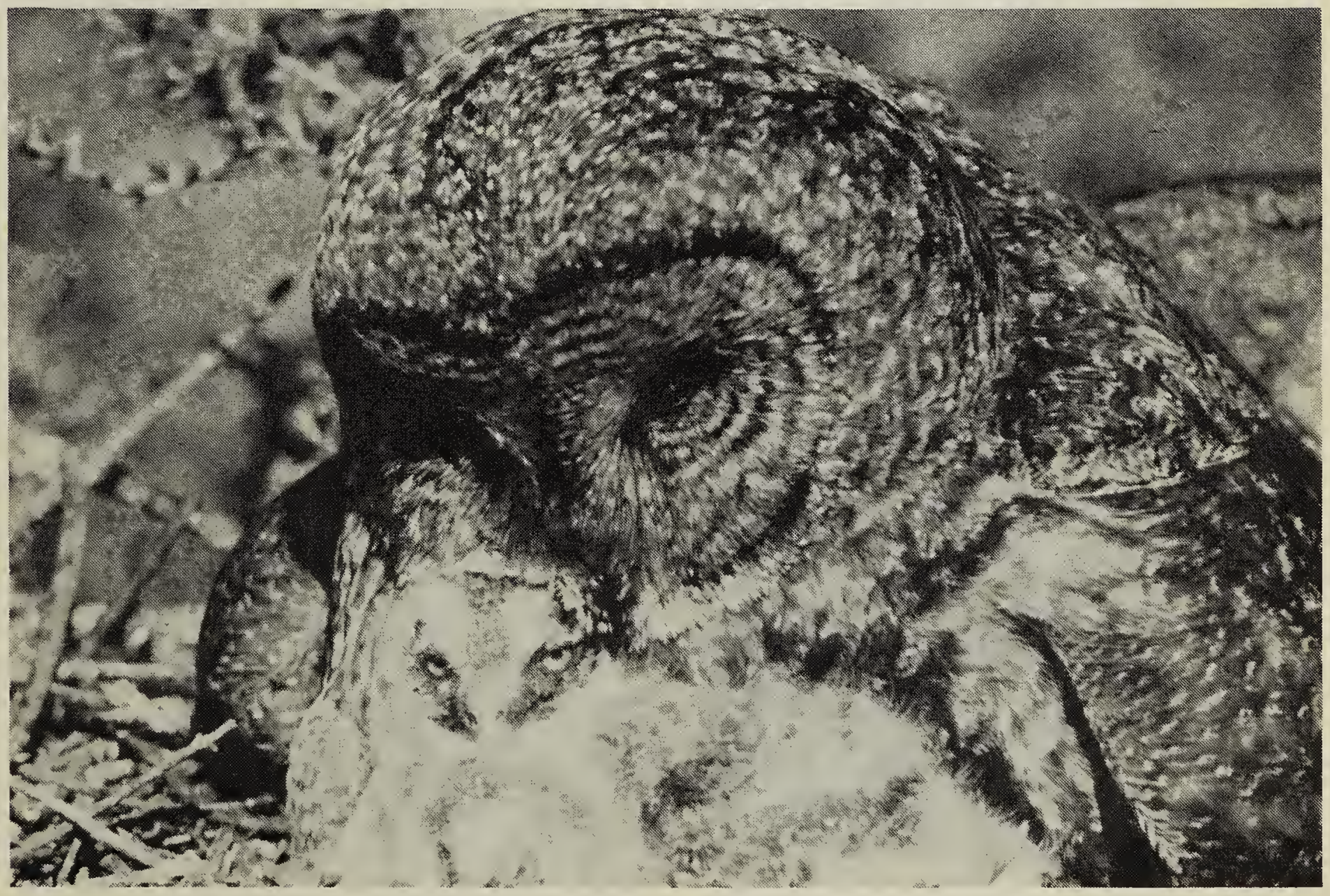

Female brooding young.

Robert R. Taylor 
In winter 1980-81 in Manitoba of 50 owls killed in a relatively small area, 44 , or $88 \%$, were immatures from the previous summer, and of 24 other owls banded that season in that area, 20 , or $83 \%$, were immatures. ${ }^{13}$ (On the other hand, in winter 1983-84, of 71 owls banded, five road kills, and perhaps 30 others closely observed, all were adults; evidently there was little nesting or poor survival in summer 1983.)

DISTRIBUTION OF OWLS: AIthough observations of Great Gray Owls were sought throughout the province records for the more remote areas are relatively scarce. By comparison with southern and extreme southeastern Manitoba, most areas of

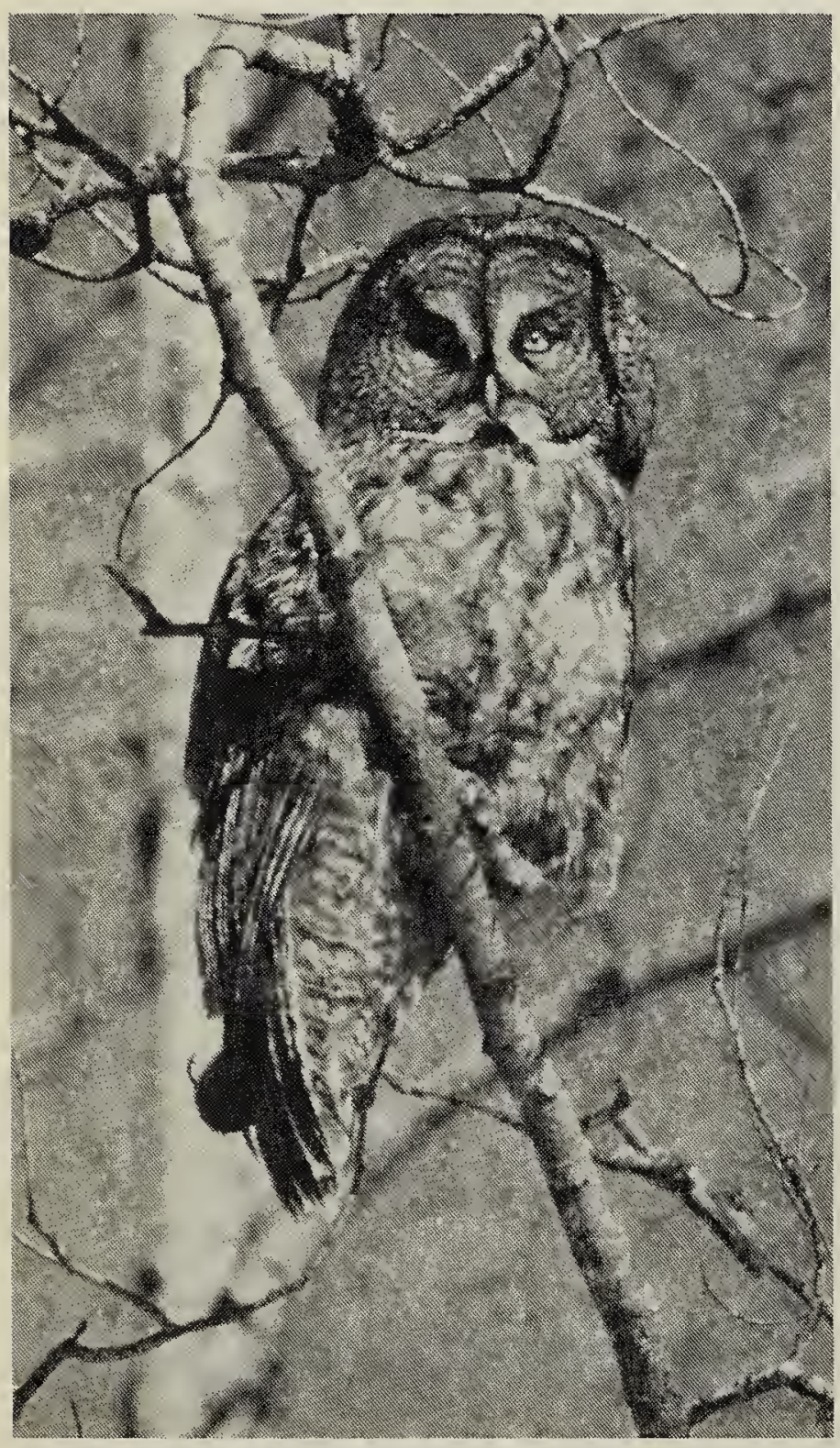

Immature owl in winter

Robert R. Taylor central and northern Manitoba have fewer roads and observers. Nonetheless, Natural Resources Officers, stationed at a number of northern cities and towns, regularly travel, in all seasons, some key roads. There are enough winter sightings in western central Manitoba to show that owls were being observed annually in that region (see Map 1). Although more observers were available in extreme southeastern Manitoba, there were fair numbers of people looking for owls in the Interlake region and elsewhere. Even within extreme southeastern Manitoba, owls were irregular in appearance, occurring in various parts of the area each winter.

NUMBERS OF OWLS: The estimated number of owls present in the province or in any particular area at any period is difficult to derive, but some data are available. In winter 1968-69, for example, it was estimated on the basis of number of sightings, area of distribution of sightings, and daily high counts, that at least 100 owls were present in extreme southeastern Manitoba. ${ }^{7}$ Owls were seen during that winter, however, over a much larger area. The total number of owls present in southern Manitoba was probably much greater.

An estimated 36 owls were present in the Lac du Bonnet area in a circle with a diameter of about $66 \mathrm{~km} \mathrm{(40}$ mi.) from 5 February to mid-March 1974. High counts within that relatively small area were 18 on 17 February, 23 February and 30 February, 17 on 2 March and 10 on 7 April. During roughly the same period (15 January - 28 February 1974), an estimated 50 owls were present in less than one township ( $36 \mathrm{sq}$. mi.) along the Summerberry River, 25 to $33 \mathrm{~km}$ (15 to $20 \mathrm{mi}$.) southeast of The Pas. Up to 15 were seen in one day by Ducks Unlimited (Canada) staff who were working along the river (Ron $L$. 
Schiedel). That area is about $500 \mathrm{~km}$ (300 mi.) northwest of the Lac du Bonnet area. South of the Summerberry River area, 11 owls were noted on the morning of 20 January 1974 , by Joe $D$. Robertson while travelling at highway speed along PTH 10 between Mafeking and "The Bog", a distance of about $50 \mathrm{~km}$ (30 mi.). During the same period ( 15 January to 28 February 1974), owls were reported from 30 other localities spanning a large region from the Duck Mountains on the west to north of the Bloodvein River on the east side of Lake Winnipeg. We had no evidence that owls were moving through the region during this period, many being seen repeatedly in the same localities over several weeks and practically none showing up at other localities. This suggests that there were at least several hundred owls present at the same time, possibly up to 1,500 , in the mixedwood and northern coniferous forest regions of the province.

In 1981, a direct count of 50 owls was obtained in a relatively small area east of Winnipeg, that number of vehicle-killed owls being retrieved from 1 January to 30 April. In addition, 24 owls were captured and banded in that area in roughly the same period. ${ }^{13}$ It was estimated that at least another 50 birds were present in the area. Several of these birds, as determined by band recoveries, were local residents.

[From January through March 1984 , more than 100 owls (of which 67 were captured and banded) were believed to be present within a circle with a diameter of less than $80 \mathrm{~km}$ (50 mi.), $48 \mathrm{~km}$ (30 mi.) northeast of Winnipeg.]

It needs to be emphasized that estimates of numbers of owls in this region do not take into account the extremely large areas of suitable habitat that were not accessible by roads. Even in extreme southeastern
Manitoba, despite a wide network of roads, only a relatively small portion of the area could be sampled. Roads that regularly produced good numbers of owls (e.g. PR 317 and PR 304) cut across extensive tracts of highly suitable range. It seems likely that estimates of numbers of owls are relatively low.

\section{WINTER CONCENTRATIONS:}

One of the striking aspects of winter appearances of Great Gray Owls has been the occasional concentration of large numbers of birds in relatively small areas. Ray and Jim Salt note that "In recent years there have been irregular winter invasions of Great Gray Owls into settled wooded regions. These are usually local in nature extending over only a small part of a province, but the number of birds may be relatively large." ${ }^{16}$ Evidently, they have included reports of owls in Manitoba in developing this statement. But the areas of concentration here are even smaller than they suggest. Even within extreme southeastern Manitoba, from winter to winter owls have not been found distributed evenly or widely, but have often been observed in restricted areas. The most dense concentration was found in late winter 1980-81, when an estimated minimum of 100 owls were present within an area approximately $45 \mathrm{~km}$ (28 mi.) in length and $8 \mathrm{~km}(5$ mi.) in width. In all cases, where birds have occurred in concentrations, an abundance of food, primarily meadow voles inhabiting meadows and roadsides, appeared to be the main causal factor.

Many observers commented on the abundance of meadow voles on Amherst Island near Kingston, Ontario, in winter 1978-79, when unusually large numbers of Great Gray Owls and other raptors crowded onto the island. Some 34 Great Gray Owls were present at the same time, with 


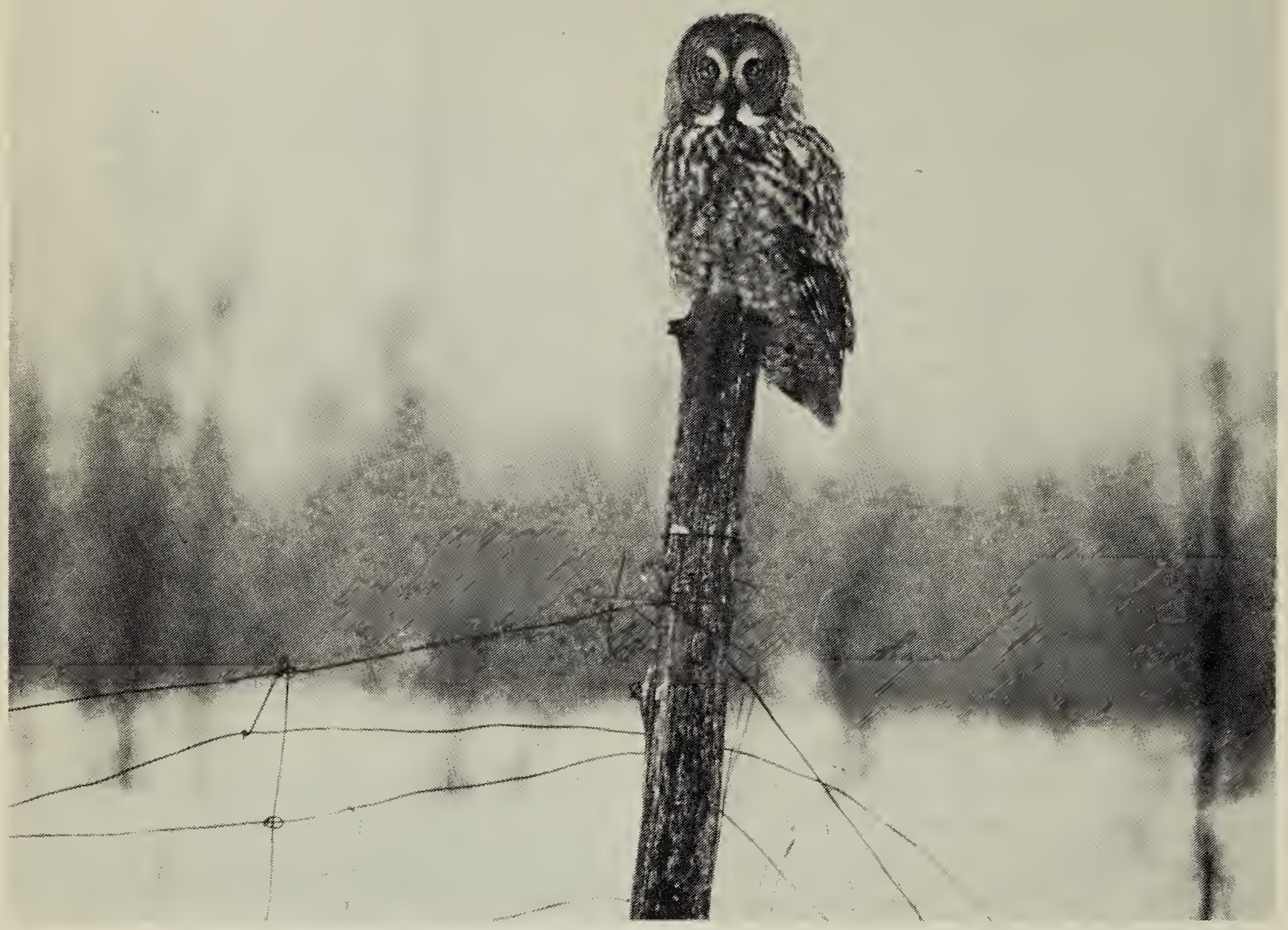

nine being seen at once in one tree (pers. comm., Fred Cooke, Richard M. Poulin, 1979). Two other observers, in an account of the widespread influx of Great Gray Owls in southern Ontario, Quebec and the New England States that winter, noted that: "Where exceptionally abundant food persists, these owls will gather in large numbers." 20

In connection with the concentrations in Manitoba, presumably scarcity of food elsewhere (as in forested areas), snow depth and icy crusts, led to movements of hungry owls to sites where prey was abundant and available. This suggests that even within the relatively small region of extreme southeastern Manitoba, vole population levels are not necessarily synchronized, but vary widely from place to place. If this is so, then it increases the difficulty of predicting owl movements, concentration points, length of stay in winter feeding sites, and effect on later nesting. But it does provide a partial explanation for the complicated and puzzling patterns of winter occurrences of owls. Nonetheless, certain areas have attracted owls often enough so that it is clear that such sites are significant winter feeding grounds, though varying annually in prey productivity.

Vole population levels measured over more than a decade at Pinawa show little relationship to winter owl sightings, though the highest meadow vole population ever measured occurred in winter 1978-79 (Steve Mihok, pers. comm., 1984), when the largest number of sightings of owls occurred (Figure 2). This was followed by one of the best breeding seasons for owls 


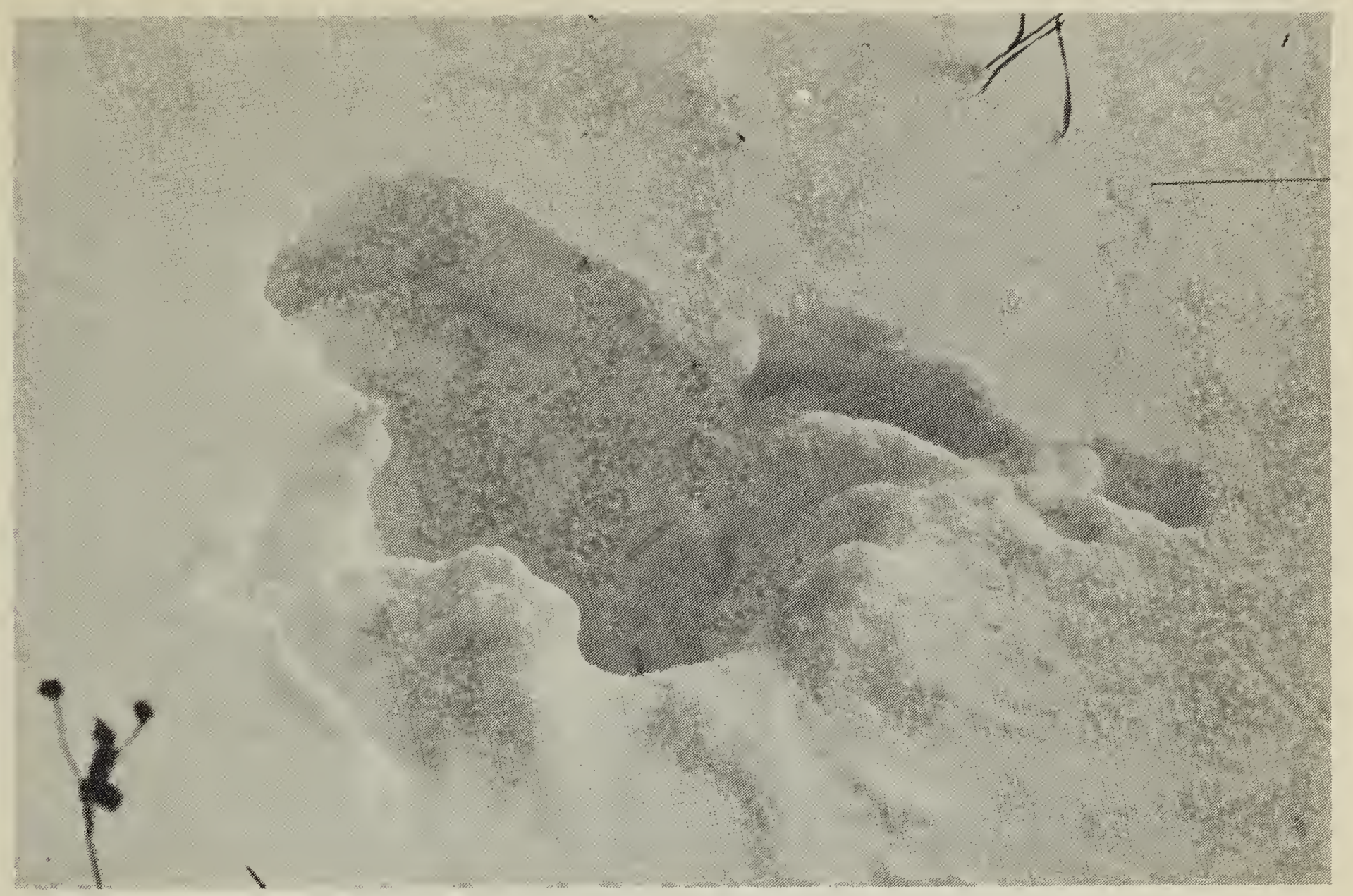

The distinctive mark left in the snow by a hunting Great Gray Owl

Robert R. Taylor

we observed (Table 1). Collins states that "The effects of the winter density of prey on the population movements of Great Gray Owls depend largely on the size of the winter Great Gray Owl population as determined by the prey densities of the previous spring and summer." The subject of owl-prey relationships is complex and merits further study.

Another little known factor in relationship to winter concentrations of owls is the distance or the direction which owls may be moving over the course of a given winter to find a food source. Although there is evidence showing that some individual birds remain in one site for weeks or even months, others (unbanded) appear over time, suggesting that some owls are forced to continue moving in search of food for longer periods than others. There is also some evidence that certain roads may act as interception lanes, temporarily attracting and halting birds (whether for food or the attractiveness of an open vista) which may have been moving through more or less solid blocks of forest. Sections of certain roads passing through good mixedwood habitat have from season to season proved to be good places to look for owls, in some instances stretches only a few kilometres in length regularly producing new birds (as shown by trapping and banding). There is reason for believing that certain wooded creek basins may function regularly as travel lanes, both for hungry birds and birds returning to familiar breeding grounds. These matters, however, are complex, requiring far more information before being understood. In terms of habitat preservation, however, it may be important to identify these and other topographical-ecological aspects of Great Gray Owl distribution and movement.

SUMMER SIGHTINGS AND BREEDING RECORDS: All of 213 summer sightings and 56 breeding records of owls (includes one nest for 1926 and 


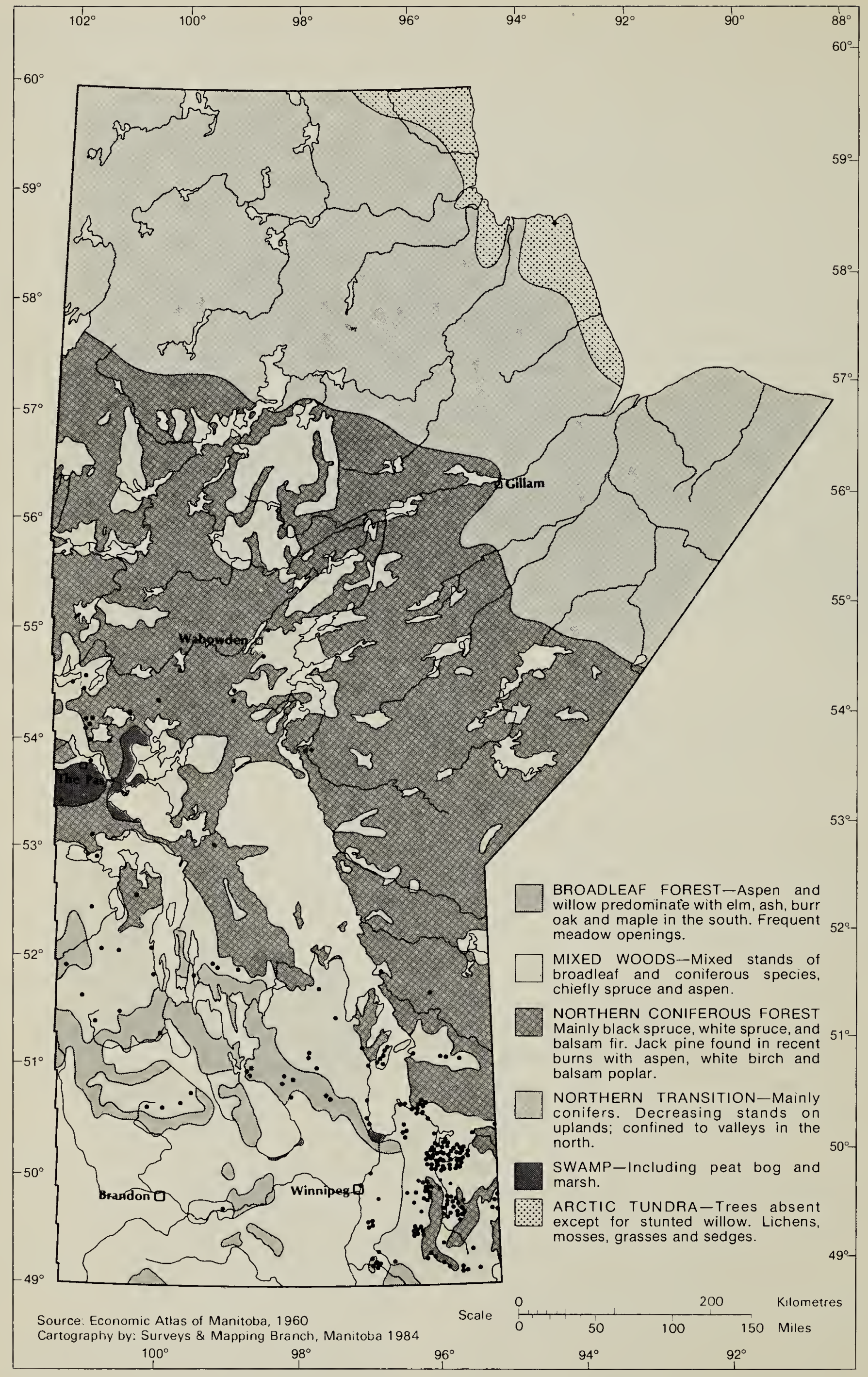

Map 2. Summer sightings of Great Gray Ow/s (May-September, 1968-83). not including breeding observations. 
1964) are shown on Maps 2 and 3, respectively. The large number of recent breeding records in extreme southeastern Manitoba is partly related to the amount of time spent looking for nests in that area and especially to the installation and successful occupancy of man-made nesting structures. The absence of natural nest structures in some blocks of habitat that were searched, plus the readiness with which man-made structures were accepted, suggests that nest structures may be a limiting factor in some habitat types. Of five nests built one December along a 3.3-km (2-mi.) stretch of road, three were occupied by owls the following April (1977). Fifty-four breeding records in 15 years (1968-83) represents a considerable increase over previous known nestings of this species in the province, but it is likely that this is only a small part of all Great Gray Owl nestings in Manitoba in this period. This species is capable of responding favourably in situations where nests are available and when small mammal populations are high. In Sweden, Ove Stefansson recorded an incredible 129 breeding records in only two years $(1981,1982) !^{18}$ How this may happen is suggested by Mikkola, who writes that: "There are some indications that nomadic Great Gray Owls move with other owls... when searching for new breeding areas after a crash in the vole population. When these invading birds find a suitable new area with plenty of voles, they may nest in loose colonies, like Short-eared Owls...."

Although there are fewer than a dozen breeding records for Manitoba outside of the extreme southeast, the records suqgest that the species breeds across the mixedwood and northern coniferous forest regions as shown by Weir. ${ }^{21}$ It also seems likely that the northern transition forest region provides suitable habitat, for Great Gray Owls have been recorded nesting in similar habitat at Moosonee, Ontario, near the shore of James Bay (pers. corr., Ken F. Abraham, 1983). In this connection, it is interesting to note that there are two sight records of Great Gray Owls beyond the transition forest in Manitoba: one was seen on 18 June 1949 near Churchill, the other on 4 June 1972 at La Perouse Bay, east of Churchill. ${ }^{2}$ Thus, Manitoba has a large expanse of potential breeding habitat for this species. It would be unwise, however, to assume that there is an unlimited amount of habitat for Great Gray Owls in Manitoba, or that they breed evenly across the forested region. Scarcity of grassy meadows within the Precambrian Shield, for example, may pose a limitation to vole populations and thus to owls.

\section{Extreme southeastern Manitoba har-} bours a good-sized breeding population (in most years), and areas in the

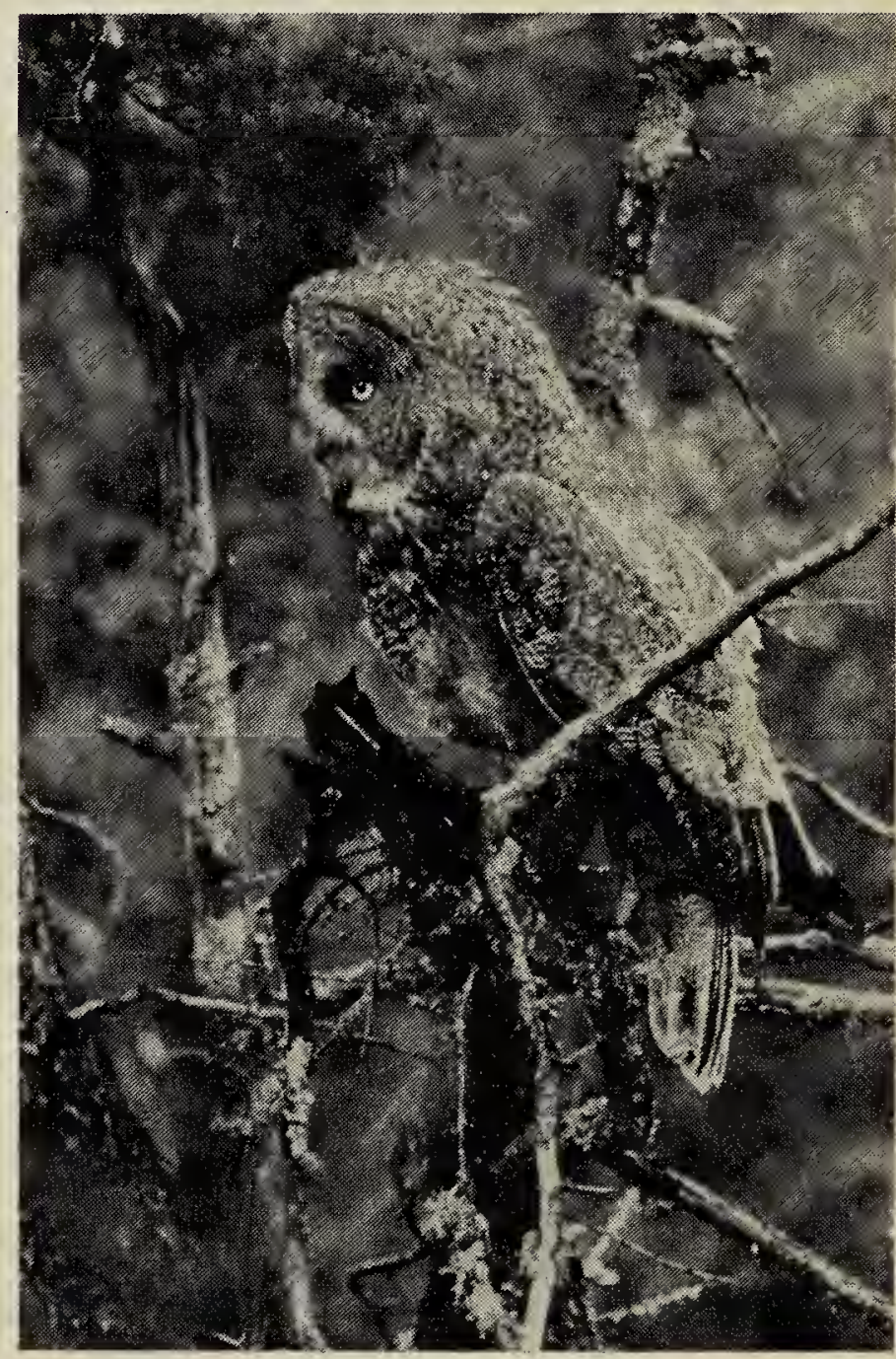

Adult female Great Gray Ow/ near nest

Robert R. Taylor 


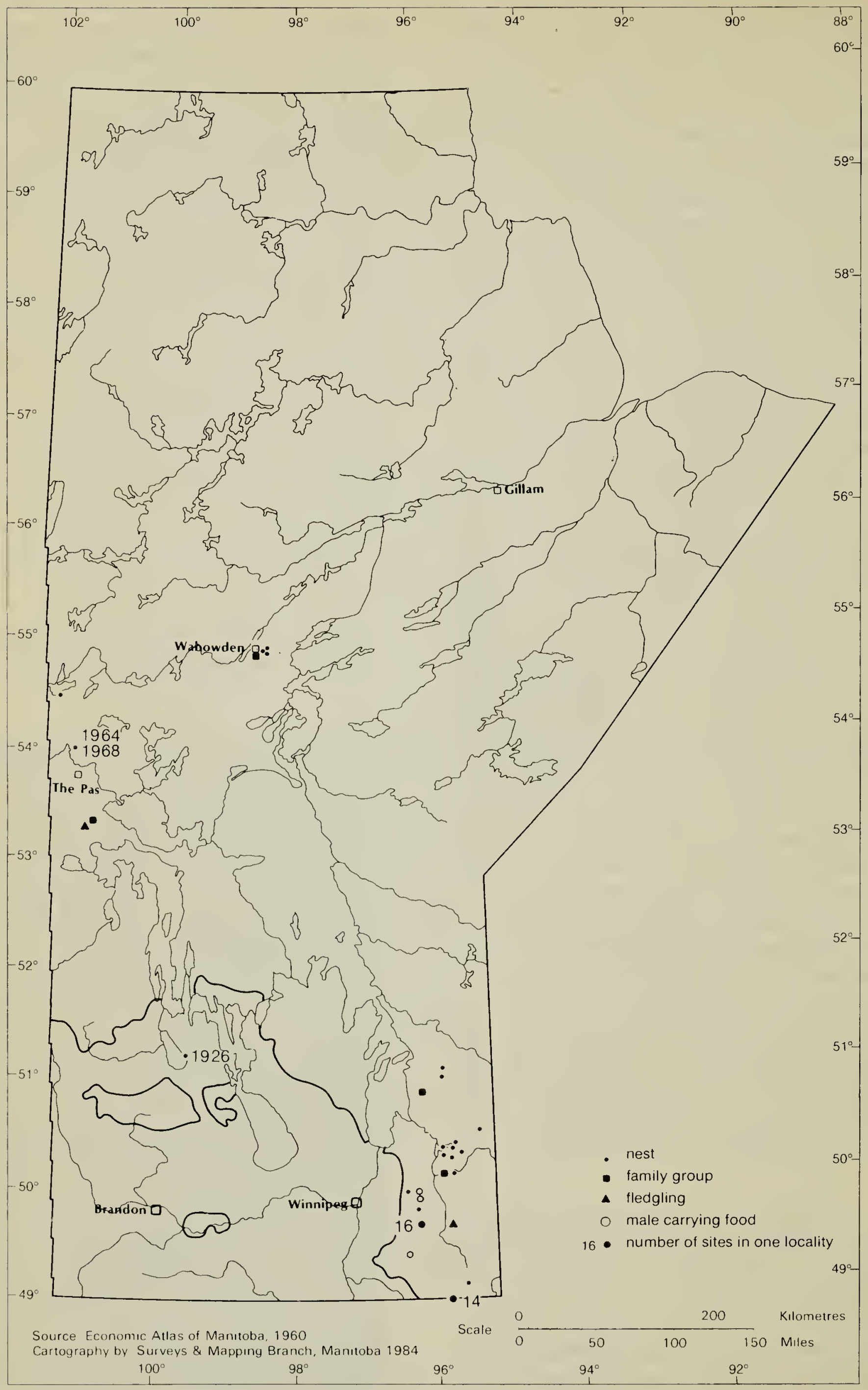

Map 3. Great Gray Owl breeding records. Nests for 1970-83, unless dated. Heavy line shows southern boundary of mixedwood region and outlying areas. 
vicinity of The Pas and northwards east of Lake Winnipeg may likewise support large numbers of owls. It is uncertain whether the species breeds in outlying areas of mixedwood habitat that appear to be suitable (e.g. Riding Mountain National Park). The late J. Dewey Soper does not mention the species ${ }^{17}$ but there are two recent summer records for the park that suggest a possibility of breeding. Park records include mention of two Great Gray Owls seen in June or July 1979, with "nesting behaviour exhibited." On 4 and 5 July 1981, two owls "presumably a pair" were observed. There is no apparent reason why the species would not nest in the park except that this is an isolated block of habitat. Their occurrence in the park, however, is uncommon, if not rare. A report of two Great Gray Owls seen by Calvin Cuthbert in June 1973 in the much smaller and more isolated Spruce Woods area east of Brandon (Map 2) further suggests occasional nesting in these sites. An early record of a Great Gray Owl at Carberry (in the Spruce Woods area) is of interest; Thompson (E.T. Seton) collected one there on 29 September $1884 .{ }^{19}$ That the species can nest outside the mixedwood region is shown by $\mathrm{E}$. Robinson's 1926 nest at Dauphin Lake. ${ }^{7}$

OWLS FOUND DEAD: The low number of owls hunting on roadsides in the summer period is reflected in the number killed or found dead. From 1969 to 1982 only 10 were found in summer compared to 173 in the winter months during the same period. This gives a total of 183 known dead owls in 15 years; it does not include a few injured owls that were placed in captivity in zoos or rehabilitation centres. In winter 1968-69, at least 10 were known to have been shot. In winter 1969-70, 11 were found shot. The total during the 15-year period is a minimum of 26 shot birds. There were 157 that were killed accidentally through collision with motor vehicles. Other mortality factors include: collision with trains -2 , accidental trapping 2 (probably larger), predation by Great Horned Owl - 3, electrocution -2 , barbed wire -1 . The greatly reduced number of shot owls from 1971 to 1983 suggests that the intensive Great Gray Owl publicity campaign markedly affected the attitude of people toward the species. One resident of southeastern Manitoba said he was certain that these activities had improved people's thinking about owls and raptors in general in this area. It is well known that in some years numbers of Great Gray Owls perish from starvation. This factor, however, is difficult to measure. In this region, motor vehicle collision casualties remain the most conspicuous mortality factor for the species. Illegal shooting remains a problem. Any official change in law or attitude towards these relatively bold and conspicuous birds is likely to affect the degree to which they are subject to gunning. Every effort should be made to maintain and increase the present level of respect and appreciation generally held by the public for these and other raptors.

\section{Discussion}

The appearance of Great Gray Owls in extreme southeastern Manitoba in winter 1968-69 was regarded as an "influx" of owls; some long-time residents of the area even reported that the species had rarely been seen before that winter. ${ }^{7}$ Later, upon discovering that Great Gray Owls were apparently present and breeding annually in this area, this point of view changed; more emphasis was placed on the status of owls observed here in winter as local residents. With accumulating information, particularly band recoveries indicating movement of birds between Manitoba and Minnesota (both north and south), it became apparent that the situation 
was fairly dynamic. The emerging picture of the Great Gray Owl in Manitoba generally is one of fluctuating numbers, both in terms of birds in summer and in winter, and with varying reproductive success relative to small mammal populations (though this still requires documentation within this region). Less is known about the summer population of owls because of the reclusive nature of the species during that season. This is complicated by apparent variations in prey populations over even short distances (more so in winter?), and changing prey levels over time. Winter populations of owls are generally more subject to measurement than summer populations, although it is clear that in winter mainly food-stressed individuals are being observed.

Mikkola reports from Scandinavia that this species does not show any adaptability to declining prey populations, which would facilitate a sedentary existence, and allow it to remain on the breeding grounds in years of poor food supply without breeding. He concludes that most of the population leads some sort of nomadic life. ${ }^{5}$ This would seem to supply a satisfactory explanation for the variable numbers observed in Manitoba over the 15 years of this study. Much more information is required on population size and density before it will be possible to determine how this species is faring. More attention as well will have to be given to small mammal populations and their requirements in diverse habitats within the breeding range of this owl.

There seem to be more Great Gray Owls in southern Manitoba now than in earlier years. Accounts of "invasions" of owls in the Winnipeg area in the $1920 \mathrm{~s}^{7}$ suggest that the phenomenon of increases or conspicuousness of owls in winter is not a recent event, but what can be said about average resident populations? The absence of density figures or estimate of summer populations makes any assessment difficult. One has to bear in mind, too, that in earlier years there were far fewer roads (and it has already been shown how attractive roads are to owls, at least in winter) and fewer observers. Mikkola points out that the density of Great Gray Owl populations depends on the availability of food, high density populations only being observed during good vole years. ${ }^{4}$

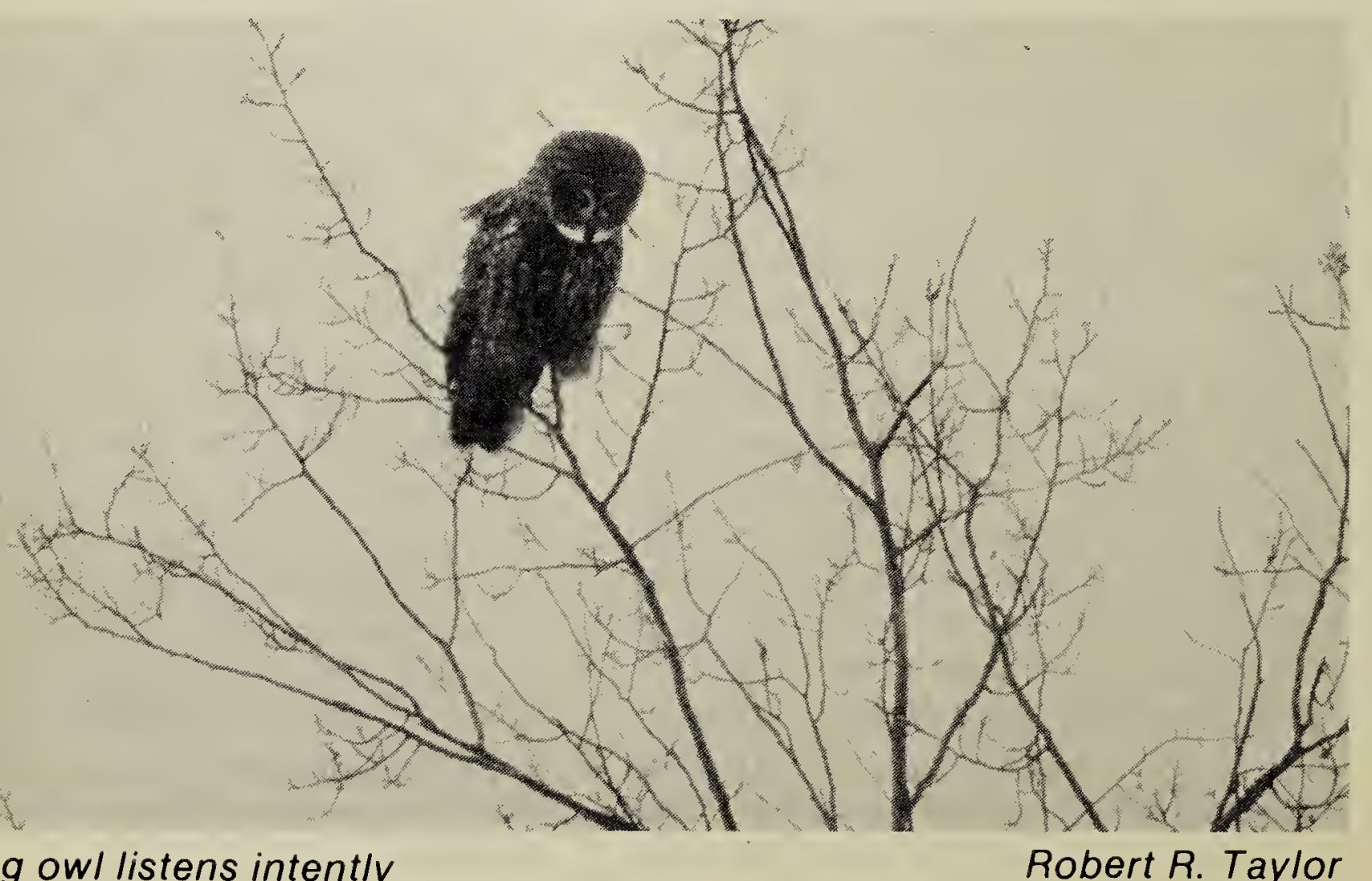


What is perhaps more to the point is Mikkola's statement that "The fact that the Great Gray Owl has become more common in Finland from 1954 to 1981 may be connected with the climate which has become colder... Kauko Hahtala, in his unpublished Ph.D. thesis, shows that climatic changes have produced a similar increase for several northern and eastern bird species in Finland, as well as for the Great Gray Owl... many more Great Gray Owls have been found breeding in peak years in the 1960s and 1970 s compared with those of the 1950s." Great Gray Owls may have increased in southern Manitoba over the past three or four decades, but until there are some data on population densities (difficult to obtain and interpret for a nomadic and fluctuating species), it will be difficult to define precisely the status of the species. In the past 15 years there appears to have been from several hundred to several thousand Great Gray Owls in Manitoba.

Does this mean that there are no management problems with the Great Gray Owl in Manitoba? As with all wildlife species, maintenance of suitable habitat is a primary requirement to ensure the continued presence of this inspiring bird. In the more remote transition forest region, fire-caused openings in the forest, subsequent growth of grass and islands of aspen poplar, plus the factors of isolation and lack of forest harvesting may continue to provide suitable habitat for the species. Over some of the commercial forest region, however, cutting practices may need to be altered to ensure that there is a place for owls. The Great Gray Owl has prospered in the midst of considerable human activity and continuous logging in extreme southeastern Manitoba. But new demands for tamarack for pulp, with widespread clearcutting now taking place in extreme southeastern Manitoba, indicate a

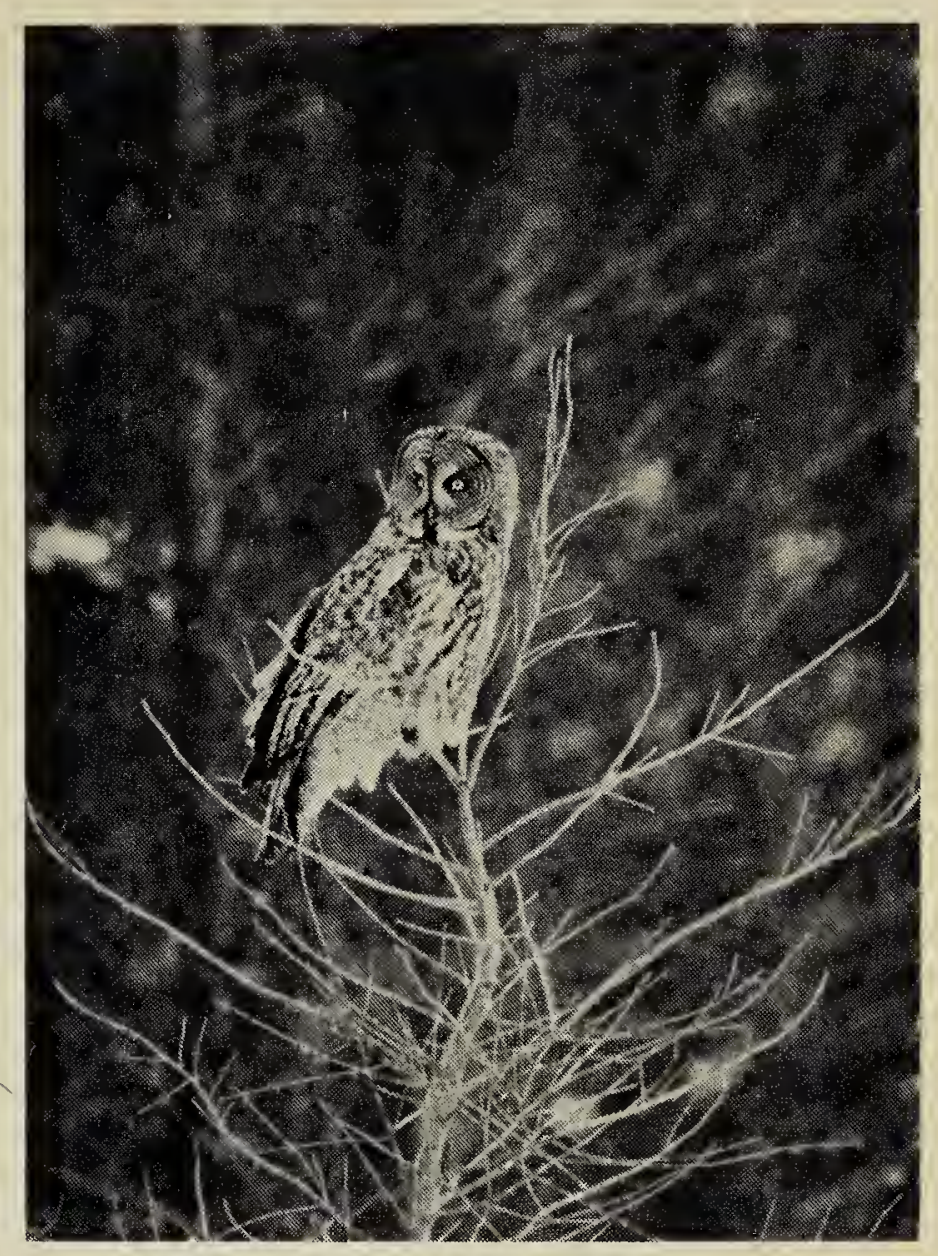

Lightweight Great Gray Ow/s perch on slender boughs Robert R. Taylor

need for new insights into owl habitat requirements, both in summer and winter. Under present tamarack harvesting methods, large blocks of nearly ideal habitat are being made uninhabitable. Clearly, there is a need for new information and adjustments of forestry practices to accommodate the needs of this species, as well as other wildlife.

New demands for peat (for mulch in Manitoba and energy in Minnesota) present another potential threat to owl habitat which needs to be evaluated. In Manitoba, especially in the extreme southeast where owls are available as a special wildlife treat to so many people, it is essential that steps be taken to ensure that there is adequate habitat. Yet there is continued pressure to develop marginal land in this region for agriculture, with demands for increased drainage and removal of trees and peat in order to grow bluegrass and other crops. Removal of mature black spruce-tamarack forest cover northwest of Lac du 
Bonnet and elsewhere is taking place continuously, with apparently little concern for the needs of furbearers and big game, let alone Great Gray Owls. Forestry practices can probably be modified (with some persuasion) to accommodate wildlife, but with the complete removal of habitat nearly all wildlife values are lost.

On the positive side, new studies of Great Gray Owls and their habitat needs are under way to attempt to answer some of the questions raised here and to make specific recommendations for forestry management to enhance or perpetuate Great Gray Owl habitat. Steve Loch from Minnesota, who is heading up the Manitoba Great Gray Owl project, already has many good ideas for altering cutting methods to benefit owls. Radiotelemetry studies by Loch are in progress to learn more about the movements of Great Gray Owls in this region and their use of habitats in all seasons. Better understanding of their habitat needs is regarded as a necessary first step in the management of this large raptor.

\section{Acknowledgements}

It is not feasible to list the names of all the people who contributed to this study, particularly the hundreds of observers who submitted records. A great debt is owing them. Regional staff of the Department of Natural Resources forwarded records from various sources. Regional staff provided access to living quarters at Piney, Hadashville, Lac du Bonnet and Ashern. Vehicles or funds for transportation and meals were made available through the Wildlife Branch of the Department of Natural Resources during several years of the study period.

Grants in support of field work were received from the Seven Sisters Falls Wildlife Association (Manitoba), the Manitoba Naturalists Society and the Frank M. Chapman Memorial Award (American Museum of Natural History). Financial support was received as a gift from Al Graham, a former fellow employee.

Numerous colour transparencies and black and white photographs of owls used for publicity purposes were supplied without charge by Robert R. Taylor. We are especially grateful to Bob Taylor for the photographs provided to accompany this article. A film produced by Bob Taylor and R. Dalton Muir was kindly made available for lecture purposes. Others who supplied colour slides include: Dave Barnes, Dan Chranowski, Michael Collins, Dennis Fast, Fred Hayward, Pat Knipe, Andy Lindsay, Gerald McKeating, Vene Parnell, Brian Ratcliff, Spencer G. Sealy, Ray Tuokko and Charles Wechsler.

The following people assisted Copland and Nero in banding one or more owls: Beverly Copland, Dan Chranowski, K. Michael Collins, Calvin Cuthbert, Karen Eastman, Jon Gerrard, Charles and Rick Gauthier, Robert E. Jones, William H. Koonz, Gerald B. McKeating, Charles Newall, Spencer G. Sealy, Robert R. Taylor and Ray Tuokko.

Particular thanks are owing for many reasons to Steven L. Loch, Spencer G. Sealy, Robert R. Taylor and Raymond Tuokko. Thanks also are due Sheldon Brown, Dan Chranowski, John Christie, Gary Friesen, Charles Gauthier, Rick Gauthier, Richard C. Goulden, Walter Krivda, Diane Kunec, William Nakka, Richard Robertson, Henry Schmidt, Merlin W. Shoesmith, William Sitar, Bill Stilwell, Jim Ticknor and John Watling.

Charlotte Chranowski translated Der Bartkauz into English. 
The figures were kindly drafted by Walter Lysack. Drafting expertise for the maps was provided by Fritz Engel and Dave Perry. NEED employee Patricia Bordynuik painstakingly plotted the 795 sightings on Map 1 , and the sightings and records on Maps 2 and 3. Typing was done by Dorothy Ball.

Special thanks go to Spencer G. Sealy for his critical and helpful review of the manuscript; no doubt in some instances he will be dissatisfied with the results, but all of his comments were given serious consideration. Steven L. Loch also reviewed the manuscript and offered many useful suggestions.

1 COLLINS, K.M. 1980. Aspects of the biology of the Great Gray OwI. M.Sc. thesis, University of Manitoba, Winnipeg.

${ }^{2}$ COOKE, F., A.J. PAKULAK, R.K. ROSS and R.K. SCHMIDT. 1975. Birds of the Tundra biome at Cape Churchill and La Perouse Bay. Canadian FieldNat. 89: 413-422.

${ }^{3}$ JEHL, J.R. Jr. and B.A. SMITH. 1970. Birds of the Churchill region, Manitoba. Spec. Pub. No. 1, Man. Museum of Man and Nature, Winnipeg. 87 pp.

${ }^{4}$ MIKKOLA, H. 1981 Der Bartkauz [The Great Gray Owl]. Die Neue BrehmBücherei 538. [A. Ziemsen Publishing House]. Wittenberg, GDR. 124 pp.

${ }^{5}$ MIKKOLA, H. 1983. Owls of Europe. Buteo Books, Vermillion, South Dakota. 397 pp.

${ }^{6}$ MUIR, D. 1972. At a nest of the Great Gray Owl. Nature Canada 1: 20-22.

${ }^{7}$ NERO, R.W. 1969. The status of the Great Gray Owl in Manitoba, with special reference to the 1968-69 influx. Blue Jay 27: 191-209.

${ }^{8}$ NERO, R.W. 1970a. A visit to a Great Gray OwI nest. Ontario Naturalist 8: 4-7.
${ }^{9}$ NERO, R.W. 1970b. Additional Great Gray Owl records for Manitoba and adjacent Manitoba. Blue Jay 28: 7273.

10 NERO, R.W. 1970c. Great Gray Owls nesting near Roseau. Loon 42: 88-93.

11 NERO, R.W. 1976. Great Gray OwI nests: building homes for rare birds. Manitoba Nature 17 (4): 4-11.

${ }^{12}$ NERO, R.W. 1980. The Great Gray Owl: phantom of the northern forest. Smithsonian Institution Press, Washington, D.C. $167 \mathrm{pp}$.

${ }^{13}$ NERO, R.W. and H.W.R. COPLAND. 1981. High mortality of Great Gray Owls in Manitoba - winter 1980-81. Blue Jay 39: 158-165.

${ }^{14}$ NERO, R.W., S.G. SEALY and H.W.R. COPLAND. 1975. Great Gray Owls occupy artificial nest. Loon 46: 161-165.

15 PARMELEE, D.F. 1968. Nesting of the Great Gray Owl in Manitoba. Blue Jay 26: 120-121.

${ }^{16}$ SALT, W.R. and J.R. SALT. 1976. The birds of Alberta. Hurtig Publishers, Edmonton. 498 pp.

17 SOPER, J.D. 1953. The birds of Riding Mountain National Park, Manitoba, Canada. Can. Dept. Resources and Develop., Natl. Parks Br., Can. Wildl. Serv. Mgt. Bull. Ser. 2, No. 6, 54 pp +8 figs., 1 map. Mimeo.

18 STEFANSSON, O. 1983. Lappugglan Strix nebulosa i Sverige 1979-82. (The Great Gray Owl in Sweden 197982). Vår Fågelv̈ard 42: 245-250.

19 THOMPSON, E.E. (E.T. Seton). 1891. The birds of Manitoba. Proc. US Natl. Mus. 13: 457-643.

${ }^{20}$ VICKERY, P.D. and R.P. YUNICK. 1979. The 1978-1979 Great Gray Owl incursion across northeastern North America. American Birds 33: 242-244.

${ }^{21}$ WEIR, T.R. 1983. Atlas of Manitoba. Surveys and Mapping Branch, Department of Natural Resources, Winnipeg. 